\title{
Curriculum Development of Educational Technology Based On the Strengthening of Courses Expertness Group
}

\author{
Sulthoni, Agus Wedi, Eka Pramono Adi \\ State University of Malang, Malang, Indonesia \\ e-mail: sulthoni.fip@um.ac.id
}

\begin{abstract}
This research is aimed to provide an in-depth study on the method of curriculum development based on strengthening the expertness in supporting the profession of educational technology. This study used a qualitative approach, and conducted at the Laboratory of Educational Technology State University of Malang. The data were searched through observation, interview, and documentation. Results showed that the curriculum has been constructed based on: (1) vision, mission, and its targets, competencies of the graduates, (3) reviews results delivered by the experts, practitioners, alumni, stake holders, and (4) graduate assessment needs. The profession of educational technology was developed scientifically. Educational technology is a study and ethically practiced to facilitate learning performance through creating, using, and managing adequately the resources of technological process. In Indonesia this area has a common paradigm generated from the science of education, not the design product.
\end{abstract}

Keywords: curriculum, educational technology, courses' expertness group

\section{INTRODUCTION}

Educational Technology, according to Januszewski (2013) is a study and an ethical practice to facilitate the learning and improve the performance through creating, using, and managing the proper resource and technology process. Although there are many variations of educational technology in Indonesia, generally they have the same paradigm. Educational technology in Indonesia was born from education science cluster, not engineering science.

Study in educational technology means an understanding effort and practice towards the educational technology. Educational technology needs a continuous construction of knowledge and enhancement through reflective in a certain period. It means that the research refers to the collection of information and analysis beyond the conception of traditional research. Research with traditional conception is qualitative and quantitative research. The research might come as some forms of theorization, philosophical analysis, historical investigation, development project, fault analysis, system analysis, and evaluation. Traditional research only generalizes the new ideas and evaluative process to help improve the practice. The research can be conducted based on some methodological constructions and theoretical constructions. Research in educational technology has developed from a study that tries to testify that media and technology is the effective means for learning, into a study formulated to investigate the accuracy of process and technology to improve the learning process.

Practical activity is a practice supported by the code of professional conduct of educational technology. Association of ethic commitees has been actively defining the ethic standard and giving some sample cases which discuss and understand the implication of the concern of practices. Moreover, recently the emphasis in society about the use of media ethics and respecting the intellectual properties has been signed by educational technology association. The ethic codes ada 1) commitment towards the individual, 2) commitment to the society, 3) commitment to the profession.

\section{METHODS}

\subsection{Approach and Research Methods}

Based on the research focus, this research used qualitative approach. Moleong (2012:6) concludes that qualitative research is a research which intends to understand the phenomenon about what is experienced by the 
subject such as behavior, perception, motivation, action, etc. holistically, and uses description of words and language, in a specific context utilizing many scientific methods. This qualitative approach used case study type. According to Wiyono (2007:77), case study is "a series of investigation to describe and analyze intensively in detail a phenomenon or a certain social unit, such as individual, group, community, or institution". With this case study approach, the researcher wanted to discover the object, which is the student interest.

\subsection{Research Location}

This research took place in Teknologi Pendidikan Universitas Negeri Malang. The place was chosen since the researcher works there and he could easily observe the real events.

\subsection{Data Source}

This research used the primary data. They are the observation and interview results. The data was taken during the observation of learning process. The interview data was collected from the interview with the research subjects from the students of educational technology who took online based subjects.

\subsection{Data Collection Procedures}

This research used some data collection procedures:
1. Observation
2. Interview
3. Documentation

\subsection{Data Analysis}

According to Patton (in Moleong 2012:280) data analysis is "a process of setting the order of data, organizing into a pattern, categorizing and one description." Moleong (2012:280) defines data analysis as a process of organizing and sorting the data into a pattern, category, and a basic description so that there is a formulated theme.

\section{RESULT AND DISCUSSION}

Analysis of The relevance between vision, mission, purpose, and the objective of study program

The forming of vision, mission, purpose, and the target of TEP study program cannot be seperated from the vision, mission, purpose, and the target set by the organization.
In other words, the vision, mission, purpose, and the target of TEP to the vision and mission of the faculty and university. It is because institutionally TEP is the integral part of FIP and UM.

The relevance of vision, mission, and the target of TEP is well achieved because during the formulation, development, consolidation, and validation it has been through some systematic process, whether in its forming or validation and its implementation. Vision, mission, and the target of TEP becomes the guidelines of its formation of achievement strategy then translated into strategic plan and the whole TEP implementation program. Connectivity, alignment and component compatibility of Vision, mission, and the target of TEP with the strategy, plan, program and activities of TEP are always reviewed and communicated to every component of TEP, especially the lecturers and students, also the graduates and alumni of TEP. The place for reviewing and updating the Vision, mission, the target of TEP, strategy, plan, and program and TEP activities is through meeting and conference, communication forum, alumni gathering, and visitation or invitation of training institutions which become the partners of TEP in students' PPL activities. Some other activities are education exhibition in university, faculty, or HMJ of TEP itself.

Analysis of Curriculum and Teachers

Strength, the curriculum of TEP is based on (1) vision, mission, purpose, and target that have been established, (2) competence that has to be achieved by the graduates, and (3) the result of the study from the experts, practitioners, graduates, and stakeholders towards the curriculum, and (4) analysis of the employment needs from TEP graduates.

Weakness, not all teaching staffs have participated, adapted, and conducted today's scientific development so that the update is slow.

Opportunity, there are some ease of access for the materials to revise and improve the quality of curriculum.

Threat, demands of science and technology development and the fast progress of society while the curriculum of TEP is reviewed in every 4 years. This makes the declining of relevance and update of curriculum.

Result of Technology Profession Description Based on Scientific

TEP is a study and practically an ethical practice to facilitate the learning process and improve the performance by creating, using, and managing the right resource and 
technology. Although there are many variations of educational technology in Indonesia, generally they have the same paradigm. Educational technology in Indonesia was born from education science cluster, not engineering science.

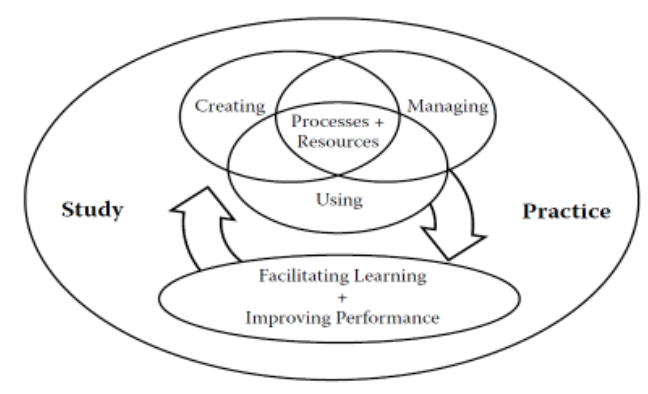

Figure 1. Picture of TEP Elements Definition

Study in TEP means an attempt to understand and practice towards the educational technology. TEP needs a continuous knowledge construction and enhancement through researches and reflective practices in a certain period. It means that the research refers to the information collection and analysis beyond the traditional research conception. The research might come as some forms of theorization, philosophical analysis, historical investigation, development project, fault analysis, system analysis, and evaluation. Traditional research only generalizes the new ideas and evaluative process to help improve the practice. The research can be conducted based on some methodological constructions and theoretical constructions. Research in educational technology has developed from a study that tries to testify that media and technology is the effective means for learning, into a study formulated to investigate the accuracy of process and technology to improve the learning process.

Practical activity is a practice supported by the code of professional conduct of educational technology. Association of ethic commitees has been actively defining the ethic standard and giving some sample cases which discuss and understand the implication of the concern of practices. Moreover, recently the emphasis in society about the use of media ethics and respecting the intellectual properties has been signed by educational technology association. The ethic codes ada 1) commitment towards the individual, 2) commitment to the society, 3) commitment to the profession.

TEP was born from education science cluster, not engineering science. Education
Science explains that there is a shift of instruction and learning view reflected in cognitive learning theory and the constructivists have created a rethinking from the assumption about the relation between instruction and learning. The early definition of this area implies a more direct causality between instruction and learning. For instance, the official definition of AECT (Ely, 1963 ) is "the design and use of message that controls the learning process". Then, the less explicit but still implying a relatively direct relation between the well designed one and delivered learning, and effective learning. The shift of the new paradigm in learning theory is the learners' role as the constructor which according to the old paradigm is contradictive, with the learner as the recipient of knowledge. With this recognition, the ownership and responsibility of the learner has a role for the more facilitating technology rather than just a controller.

\section{REFERENCES}

[1] Australian National Training Authority (ANTA) (2005) Training Package Workplan

http://antapubs.dest.gov.au/publications/ publication.asp?qsID $=689 \quad$ (retrieved 16/03/06)

[2] Bowman, K., Clayton, B., Bateman, A., Knight, B., Thomson, P., Hargreaves, J., Blom, K. and Enders, M. (2003) Recognition of prior learning in the vocational education and training sector. National Centre for Vocational Education Research (NCVER) Boud, David. (2003) Combining Work and L

[3] Ely, d. P. (1963). The changing role of the audiovisual process in education--a definition and a glossary of related terms.

[4] Hays, J. (2005) Dynamics of Organisational Wisdom. Paper presented at the 5th International Conference on Knowledge, Culture, and Change. Rhodes, Greece. http://teaching.fec.anu.edu.au/BUSN803 0/

Dynamics $\% 20$ of $\% 20$ Organisational $\% 20$ Wisdom $\% 20-\% 20$ Trento $\% 20$ Version.doc (retrieved 15/03/06)

[5] Januszewski, A., \& Molenda, M. (Eds.). (2013). Educational technology: A definition with commentary. Routledge.

[6] Lofland, J., \& Lofland, L. (1984). Analyzing social settings: A guide to 
qualitative observation and analysis (2nd ed.). Belmont, CA: Wadsworth

[7] Moleong, L. J. 2012. Metodelogi

Penelitian Kualitatif (Edisi Revisi). Bandung: PT Remaja Rosdakarya.
[8] Weigel, Van B. (2001). Deep Learning for a Digital Age: Technology's Untapped Potential to Enrich Higher Education. San Francisco: Jossey Bass Wiley. 